\title{
A New Opioid Free Postoperative Pain Relief Technique for Pediatric Laparoscopic Appendectomy: Erector Spinae Plane Block
}

\author{
Pediatrik Laparaskopik Apendektomide Opioidsiz Postoperatif Ăgrı \\ Tedavisinde Yeni Bir Teknik: Erektör Spinae Plan Bloğu
}

\author{
Ali İhsan UYSAL ${ }^{1}$, Başak ALTIPARMAK ${ }^{2}$, Melike KORKMAZ TOKER ${ }^{2}$, \\ Süleyman Cüneyt KARAKUŞ ${ }^{3}$, Semra GÜMÜŞ DEMIRBILEK ${ }^{2}$ \\ ${ }^{1}$ Muğla Training and Research Hospital, Department of Anesthesiology and Reanimation, Muğla \\ ${ }^{2}$ Muğla Sitkı Koçman University, Faculty of Medicine, Department of Anesthesiology and Reanimation, Muğla \\ ${ }^{3}$ Muğla Sitkı Koçman University, Faculty of Medicine, Department of Pediatric Surgery, Muğla
}

\begin{abstract}
$\ddot{\mathbf{O} z}$
Erektör spinae plan bloğu (ESPB) yeni tanımlanmıs interfasyal bloktur ve özellikle postoperatif analjezi için uygulanmaktadır. Literatürde değişik endikasyonlarda kullanılmaktadır. Erektör spinae alan bloğu uygulandığında lokal anestezikler multilevel yayılım göstermektedir. Tek enjeksiyon ile multilevel analjezi sağlanabildiği için avantaj yaratmaktadır. Pediatrik hastalardaki laparaskopik apendektomi cerrahisinde erektör spinae alan bloğu postoperatif opioidsiz ağn tedavisi için uygun bir seçenek olabilir.

Anahtar Kelimeler: Erektör Spinae Alan Bloğu, Laparaskopik Apendektomi, Postoperatif Analjezi, Pediatrik Hasta
\end{abstract}

\section{Introduction}

Postoperative pain relief in pediatric patients is important since they cannot express themselves well enough. Oral and rectal administration of nonopioid drugs and regional anesthesia play a crucial role since they are available in most places (1). Good use of these modalities has an important opioid-sparing effect (2).

Although opioids are commonly used for postoperative analgesia they have some side effects. The use of regional anesthesia in the pediatric population has increased over the last decade as it offers several potential advantages in the provision of postoperative analgesia including a reduction in parenteral opioids, decreased exposure to general anesthetic agents, and shortened hospital length of stay $(3,4)$. Regional analgesia continues to evolve with the introduction of ultrasound-guided fascial plane blocks.

The ESPB is a novel technique targeting the ventral rami, dorsal rami, and rami communicantes

\begin{tabular}{|c|c|}
\hline & ORCID No \\
\hline Ali İhsan UYSAL & $0000-0002-3320-4558$ \\
\hline Başak ALTIPARMAK & 0000-0002-8165-3438 \\
\hline Melike KORKMAZ TOKER & 0000-0003-1916-4454 \\
\hline Süleyman Cüneyt KARAKUŞ & $0000-0003-4283-6263$ \\
\hline Semra GÜMÜŞ DEMIRBILEK & 0000-0001-7721-4582 \\
\hline Başvuru Tarihi / Received: & 25.11.2019 \\
\hline Kabul Tarihi / Accepted : & 08.03.2020 \\
\hline Adres / Correspondence : & Ali İhsan UYSAL \\
\hline $\begin{array}{l}\text { Muğla Training and Resea } \\
\text { Anesthesiology and Reanimation }\end{array}$ & $\begin{array}{l}\text { rch Hospital, Department of } \\
\text { Muğla }\end{array}$ \\
\hline e-posta / e-mail & alihsanuysal@gmail.com \\
\hline
\end{tabular}

\begin{abstract}
Erector spinae plane block (ESPB) is a new interfasial block and especially utilizing for postoperative analgesia. In literature it has different indications. Local anesthetics can spread multilevels in erector spinae plane. This gives advantage about one injection and multilevel analgesia. Erector spinae plane block can be a good choice for postoperative opioid free pain relief of laparoscopic appendectomy surgeries in pediatric patients.
\end{abstract}

Keywords: Erector Spinae Plane Block, Laparascopic Appendectomy, Postoperative Analgesia, Pediatric Patient

of the spinal nerves. After injection, the local anesthetic agent was shown to extend cranially and caudally over several dermatomal levels. ESPB is utilizing for postoperative analgesia in different adult and pediatric surgeries (5-7).

Case

A parental written consent was obtained for each patient for the block procedure. Also a different written consent was obtained from parents of each patient about publication of the case.

After the induction of general endotracheal anesthesia, the patients was positioned in the left lateral decubitis position a high frequency linear ultrasound probe was placed. After allowing transvers processes at $\mathrm{T} 11$ and T12 levels the esp block with $0.5 \mathrm{ml} / \mathrm{kg} 0.25$ bupivakain was done at $\mathrm{T} 11$ for two patients and it was done at T12 level for three patients (Figure 1 and 2). A 20 G Tuohy needle was inserted in plane with caudal to cephalad approach to beneath the erector spinae muscles plane.

After the application of ESPB the patient was brought back to the supine position and then was given permission to beginning of surgery. $10 \mathrm{mg} / \mathrm{kg}$ paracetamol was given intravenously. There was not any remarkable event in the duration of operations.

The patients were evaluated with The Face Legs Activity Cry Consolability (FLACC) Scale which was developed by the Department of Anesthesiology, University of Michigan Medical School and Health Systems. The FLACC Scale is a behavioral scale for scoring postoperative pain in 
Table 1. Age, level of block, time of surgery and FLACC scores of patients

\begin{tabular}{|c|c|c|c|c|c|c|c|c|}
\hline Age & $\begin{array}{c}\text { Level of } \\
\text { ESP block }\end{array}$ & $\begin{array}{c}\text { Time of } \\
\text { surgery } \\
\text { (minutes) }\end{array}$ & $\begin{array}{c}\text { FLACC } \\
5 . \mathrm{min}\end{array}$ & $\begin{array}{c}\text { FLACC } \\
15 . \mathrm{min}\end{array}$ & $\begin{array}{c}\text { FLACC } \\
1 . \text { hour }\end{array}$ & $\begin{array}{c}\text { FLACC } \\
6 . \text { hours }\end{array}$ & $\begin{array}{c}\text { FLACC } \\
12 . \text { hours }\end{array}$ & $\begin{array}{c}\text { Additional } \\
\text { analgesic }\end{array}$ \\
\hline 2 & T11 & 65 & 2 & 0 & 0 & 0 & 0 & 0 \\
\hline 9 & T11 & 50 & 1 & 0 & 1 & 0 & 0 & 0 \\
\hline 6 & T12 & 55 & 0 & 1 & 0 & 0 & 0 & 0 \\
\hline 4 & T12 & 60 & 0 & 0 & 0 & 0 & 0 & 0 \\
\hline 4 & T12 & 70 & 1 & 0 & 0 & 1 & 0 & 0 \\
\hline
\end{tabular}

children between the ages of two months and seven years or in persons unable to communicate. The evaluation of patients was done at 5 . and 15 . minutes in recovery room and at $1 ., 6$. and 12 . hours in ward. The results of evaluations were shown in Table 1.

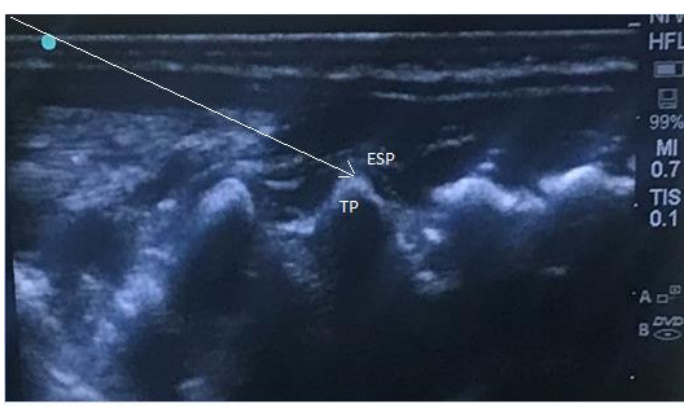

Figure 1. The linear ultrasound view for ESPB Arrow: The pathway of needle; TP: The tranvers process of vertebrae; ESP: The Erector Spinae Muscle

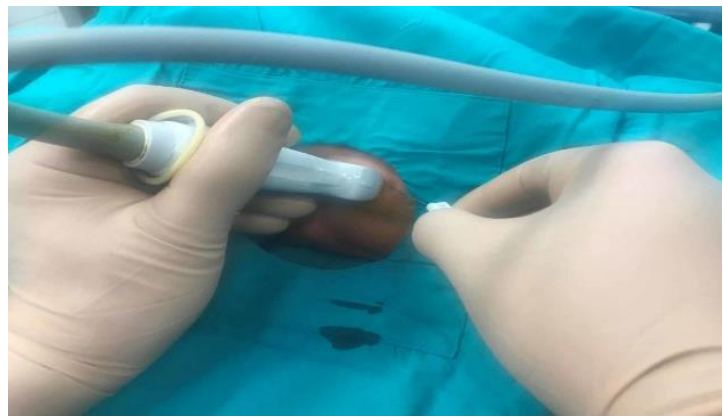

Figure 2. The photo of Erector Spinae Plane Block procedure

\section{Discussion}

Postoperative effective analgesia should be planned for pediatric patients. Small children may become more severely agitated, since they are more dependent on their parents, have a lower tolerance for fasting, less flexibility with strange settings, and a lower pain threshold. One of the most important causes of postoperative agitation is pain (8).

A study published in 2008 of 12.739 surgical inpatients noted a correlation between persistent perioperative opioid use following surgical procedures and mortality (9). For this multimodal analgesia is recommending for postoperative analgesia.

Caudal anesthesia/analgesia is one of the part of multimodal analgesia in children. It is the most popular regional blocks in children and is efficacious for postoperative analgesia for infraumbilical procedures (10). Caudal anesthesia has some side effects and complications. These are total spinal anesthesia, urinary retention, epidural abscess, epidural hematoma and paraplegia $(11,12)$.

Erector Spinae Plane Block is a new block and mechanical complications are rare as local anesthesia application is performed distant to any nerve or vital organ (13).It is recommended a part of postoperative multimodal analgesia in pediatric patients for decreasing opioid consumption(14). It has showed by cadeveric studies (15) and clinic studies (16) local anesthetics can spread in erector spinae plane fascia. We are reporting here that single shot ESPB can be used for opioid free pain relief in laparoscopic appendectomy surgery.

The ESPB is mainly use for lower abdominal surgeries in pediatric patients. ESPB is an interfacial block and local anesthetics can be spread to the paravertebral and epidural space. In a study (17) was shown that the ESPB is effective for several indications from $\mathrm{T} 2$ vertebral level to $\mathrm{L} 1$ level.

Our cases seem to be a new indication for postoperative analgesia by ESPB.

The paravertebral block (18) at T12-L1 level and transverses abdominis plane (TAP) block (19) can be utilized in pediatric appendectomy surgeries. The FLACC scores and rescue analgesic and total opioid consumption showed that ESPB can solve the pain problem of pediatric patients after appendectomy.

We decided to apply ESPB as the paravertebral block would insufficient for analgesia in port hole region. The analgesia plan has to solve the pain from surgery and port hole region and the visceral pain. The ESPB can provide visceral analgesia and can spread in caudal and cephalad regions (20).

In conclusion single shot ESPB at T11 or T12 levels can be an alternative effective choice for postoperative opioid free pain treatment in pediatric laparoscopic appendectomy surgeries.

Written consent: Written consents of the patients were obtained on 07.10.2019, 16.10.2019, 24.10.2019, 01.11.2019 and 08.11.2019.

\section{References}

1. Jöhr M. Practical pediatric regional anesthesia. Curr Opinion Anaesthesiol. 2013;26(3):327-32. 
2. Yaster M, Traystman RJ. Multimodal analgesia in children. Eur J Anaesthesiol. 2010. 27(10):851-7.

3. Schloss B, Bhalla T, Klingele K, Phillips D, Prestwich B, Tobias JD. A retrospective review of femoral nerve block for postoperative analgesia after knee surgery in the pediatric population. J Pediatr Orthop. 2014;34(4):459-61.

4. Capdevila X,Barthelet Y,Biboulet $\mathrm{P}$ et.al. Effects of perioperative analgesic technique on the surgical outcome and duration of rehabilitation after major knee surgery. Anesthesiology. 1999; 91:8-15

5. Altıparmak B, Korkmaz Toker M, Uysal AI, Kuşçu Y, Gümüş Demirbilek S. Ultrasound-guided erector spinae plane block versus oblique subcostal transversus abdominis plane block for postoperative analgesia of adult patients undergoing laparoscopic cholecystectomy: Randomized, controlled trial. J Clin Anesth. 2019;57:31-6.

6. Altıparmak B, Korkmaz Toker M, Uysal Aİ, Turan M, Gümüș Demirbilek S. Comparison of the effects of modified pectoral nerve block and erector spinae plane block on postoperative opioid consumption and pain scores of patients after radical mastectomy surgery: A prospective, randomized, controlled trial. J Clin Anesth. 2019;54:61-5.

7. Uysal Aİ, Altıparmak B, Korkmaz Toker M, Gümüş Demirbilek S. Bi-level ESP block for left diaphragma hernia repair in a pediatric patient. J Clin Anesthesia. 2020.;61:109620.

8. Uğur G. The Evaluation of the Factors Affecting Emergence Agitation in Pediatric Anesthesia Practise. South Clin Istanbul Eurasia. 2018;29(1):36-44.

9. Fecho K, Lunney AT, Boysen PG, Rock P, Norfleet EA. Postoperative mortality after inpatient surgery: Incidence and risk factors. Ther Clin Risk Manag. 2008; 4(4): 681-8.

10. Jöhr M, Berger TM. Caudal block: Simple safe and effectiveResponse to Dr Dario Galante. Pediatr Anaesthesia. 2012;22(2):184-5.
11. Desparmet JF. Total spinal anesthesia after caudal anesthesia in an infant. Anesth Analg. 1990;70(6):665-7.

12. Bouchut JC, Dubois R, Foussat C, et al. Evaluation of caudal anaesthesia performed in conscious ex-premature infants for inguinal herniotomies. Paediatr Anaesth. 2001;11(1):55-8

13. Thomas DT, Tulgar S. Ultrasound-guided Erector Spinae Plane Block in a Child Undergoing Laparoscopic Cholecystectomy. Cureus. 2018;10(2):10-2.

14. Aksu C, Gürkan Y. Opioid sparing effect of Erector Spinae Plane block for pediatric bilateral inguinal hernia surgeries. $\mathrm{J}$ Clin Anesth. 2018;50(June):62-3.

15. Ivanusic J, Konishi Y, Barrington MJ. A Cadaveric Study Investigating the Mechanism of Action of Erector Spinae Blockade. Reg Anesth Pain Med. 2018;43(6):567-71.

16. Tulgar S, Selvi O, Ozer Z. Clinical experience of ultrasoundguided single and bi-level erector spinae plane block for postoperative analgesia in patients undergoing thoracotomy. J Clin Anesth. 2018;50:22-3

17. Tulgar S, Selvi O, Senturk O, Serifsoy TE, Thomas DT. Ultrasound-guided Erector Spinae Plane Block: Indications, Complications, and Effects on Acute and Chronic Pain Based on a Single-center Experience. Cureus. 2019;11(1):1-15.

18. Splinter WM, Thomson ME. Somatic paravertebral block decreases opioid requirements in children undergoing appendectomy. Can J Anesth. 2010;57(3):206-10.

19. Seyedhejazi M, Motarabbesoun S, Eslampoor Y, Taghizadieh N, Hazhir N. Appendectomy Pain Control by Transversus Abdominis Plane (TAP) Block in Children. Anesthesiol Pain Med. 2019;9(1):e83975

20. Chin KJ, Malhas L, Perlas A. The erector spinae plane block provides visceral abdominal analgesia in bariatric surgery a report of 3 cases. Reg Anesth Pain Med. 2017;42(3):372-6. 